\title{
Strength and drying shrinkage of slag paste activated by sodium carbonate and reactive $\mathrm{MgO}$
}

\author{
Fei Jin*, Abir Al-Tabbaa
}

Fei Jin: PhD candidate, Department of Engineering, University of Cambridge, Trumpington Road, Cambridge CB2 1PZ, United Kingdom

\begin{abstract}
Abir Al-Tabbaa: PhD, Reader in Department of Engineering, University of Cambridge, Trumpington Road, Cambridge CB2 1PZ, United Kingdom

* Corresponding author

Email: leonking1987@gmail.com
\end{abstract}


Abstract: This paper investigates the potential of combining $\mathrm{Na}_{2} \mathrm{CO}_{3}$ and reactive $\mathrm{MgO}$ as a sustainable activator for ground granulated blastfurnace slag. Two very different reactivity $\mathrm{MgOs}$ were added at $5-10 \%$ and the $\mathrm{Na}_{2} \mathrm{CO}_{3}$ content varied from $4 \%$ to $8 \%$ by the weight of slag. The strength and the drying shrinkage of the activated slag pastes were tested up to 90 days. It was found that the optimum reactive $\mathrm{MgO}$ addition was $5 \%$ regardless of the $\mathrm{MgO}$ type and $\mathrm{Na}_{2} \mathrm{CO}_{3}$ content. $\mathrm{MgO}$ with the higher reactivity significantly increased the early strength of the paste but had almost no effect on the strength at 90 days. On the other hand, the effect of the lower reactivity $\mathrm{MgO}$ on the strength was more profound at later ages and low $\mathrm{Na}_{2} \mathrm{CO}_{3}$ dosage. In terms of drying shrinkage, increasing the $\mathrm{Na}_{2} \mathrm{CO}_{3}$ content from $4 \%$ to $6 \%$ caused a remarkable decrease of drying shrinkage while increasing it from $6 \%$ to $8 \%$ had negligible effect. X-ray diffraction and thermogravimetric analysis revealed that the major hydration products were calcium silicate hydrate gel and hydrotalcitelike phases, similar to those in conventional alkali-activated slags. There was also a large quantity of calcite formed especially in the $8 \% \mathrm{Na}_{2} \mathrm{CO}_{3}$ pastes due to causticisation. It was concluded that the combination of reactive $\mathrm{MgO}$ and $\mathrm{Na}_{2} \mathrm{CO}_{3}$ could serve as a potential sustainable activator for slags.

Keywords: reactive $\mathrm{MgO}$, sodium carbonate, slag, strength, drying shrinkage, hydration products 


\section{Introduction}

The production of Portland cement (PC) results in $\sim 7 \%$ of man-made $\mathrm{CO}_{2}$ emissions [1], from the decomposition of limestone at $\sim 1450{ }^{\circ} \mathrm{C}$, the combustion of fuels in the kiln, as well as from power generation. Various attempts have been made in order to reduce the carbon footprint of the cement industry, one of which is the extensive usage of industrial by-products. Alkali-activated slag cements (AAS) based on ground granulated blast-furnace slag (GGBS) are sustainable alternatives to PC due to their low initial capital cost of the raw material, the saving of energy and resources, and the elimination of $\mathrm{CO}_{2}$ emissions from limestone decomposition [2]. It is estimated that $70-80 \%$ of the $\mathrm{CO}_{2}$ emissions can be reduced by substituting alkali-activated binders for PC [3].

Numerous research efforts have focussed on the activation of GGBS by various alkali-metal hydroxides and silicates such as $\mathrm{NaOH}, \mathrm{KOH}$, sodium silicate and their mixtures [4]. However, neither $\mathrm{NaOH}$ nor sodium silicate is naturally available and they both require energy-intensive manufacturing processes. $\mathrm{NaOH}$ is usually generated by electrolysis of sodium chloride solution while sodium silicate is mainly produced by melting sand together with sodium carbonate/sodium sulfate at $1100-1200{ }^{\circ} \mathrm{C}$ followed by dissolution at $140-160{ }^{\circ} \mathrm{C}$ in high pressure steam. Consequently, the production of these alkalis has a large carbon footprint which diminishes the environmental credits assigned to AAS. Therefore, AAS using high volumes of $\mathrm{NaOH}$ and sodium silicate cannot be regarded as the best option for achieving a truly low-carbon and environmentally friendly cement system [5]. In addition to these sustainability challenges, the caustic nature, high cost and significantly high drying shrinkage behaviour [6] hinder the widespread usage of AAS based on these activators.

To develop a more sustainable AAS cement, sodium carbonate $\left(\mathrm{Na}_{2} \mathrm{CO}_{3}\right)$ was proposed as an alternative activator for GGBS [7]. $\mathrm{Na}_{2} \mathrm{CO}_{3}$ can be refined from the mineral trona, or from naturally occurring sodium-carbonate-bearing brines, or alternatively manufactured from one of several chemical processes, and thus the world's resources of $\mathrm{Na}_{2} \mathrm{CO}_{3}$ are practically inexhaustible and it is 23 times cheaper than $\mathrm{NaOH}$ or sodium silicate [8]. Furthermore, $\mathrm{Na}_{2} \mathrm{CO}_{3}$ is less caustic and less harmful to the environment since it only produces carbonate anions in water. Nevertheless, research 
on $\mathrm{Na}_{2} \mathrm{CO}_{3}$ activated slag is still very limited in the literature. Fernandez-Jimenez [7] showed that at $28 \mathrm{~d}$, the strengths of alkali activated slag mortars followed the order: $\mathrm{Na}_{2} \mathrm{SiO}_{3} \cdot n \mathrm{H}_{2} \mathrm{O}+\mathrm{NaOH}>$ $\mathrm{Na}_{2} \mathrm{CO}_{3}>\mathrm{NaOH}$. The author and later studies [6,9] suggested that $\mathrm{Na}_{2} \mathrm{CO}_{3}$ activated slag pastes showed long setting times and low early strength due to the low initial $\mathrm{pH}$ and the formation of a sodium calcium carbonate which retarded the reaction process. At later ages, the strengths were higher in the case of $\mathrm{Na}_{2} \mathrm{CO}_{3}$ due to the formation of carbonated compounds such as $\mathrm{C}_{3} \mathrm{~A} \cdot \mathrm{CaCO}_{3} \bullet 12 \mathrm{H}_{2} \mathrm{O}$ [10]. Sakulich et al. [11] found that $\mathrm{Na}_{2} \mathrm{CO}_{3}$ (8\% of slag) activated slag mortar had negligible strength at $1 \mathrm{~d}$ while the strength increased to $\sim 37 \mathrm{MPa}$ at $28 \mathrm{~d}$, with $\sim 75 \%$ of this strength gained during the first week. In terms of shrinkage, Andersson and Gram [12] revealed that although the drying shrinkage of $5 \% \mathrm{Na}_{2} \mathrm{CO}_{3}$ activated slag was $\sim 60 \%$ higher than $\mathrm{PC}$ at $231 \mathrm{~d}$ of curing at $20^{\circ} \mathrm{C}$ and $80 \% \mathrm{RH}$, curing at $80^{\circ} \mathrm{C}$ for 8 hours significantly decreased the shrinkage to a value slightly lower than that of PC. In another study, Duran Atis [6] found that the shrinkage of sodium silicate and $\mathrm{NaOH}$ activated slag mortar was 3 and 6 times more than that of PC mortar, respectively; while the shrinkage of $\mathrm{Na}_{2} \mathrm{CO}_{3}$ activated slag mortar was lower or similar to PC mortar at $23{ }^{\circ} \mathrm{C}$ and $65 \% \mathrm{RH}$. Therefore, $\mathrm{Na}_{2} \mathrm{CO}_{3}$ could be a promising sustainable activator to produce lowshrinkage AAS.

In fact, $\mathrm{Na}_{2} \mathrm{CO}_{3}$ is often used with other alkaline activators such as $\mathrm{NaOH}$ or sodium silicate. Collins and Sanjayan [13] evaluated the suitability of $\mathrm{NaOH}$ and $\mathrm{Na}_{2} \mathrm{CO}_{3}$ as a joint activator for slag and compared them with PC cured at $23{ }^{\circ} \mathrm{C}$. With the addition of $\mathrm{Na}_{2} \mathrm{CO}_{3}$, the results indicated that the $1 \mathrm{~d}$ strength was generally greater than $\mathrm{PC}$ at the higher dosage levels of $\mathrm{NaOH}$ and $\mathrm{Na}_{2} \mathrm{CO}_{3}$, and there was a trend of increasing strength with increasing $\mathrm{Na}_{2} \mathrm{CO}_{3}$ dose. Similarly, Li and Sun [14] showed that the combination of $\mathrm{NaOH}$ and $\mathrm{Na}_{2} \mathrm{CO}_{3}$ gave higher strengths than using either alone. Fernandez and Puertas [9] investigated the combination of sodium silicate, $\mathrm{NaOH}$ and $\mathrm{Na}_{2} \mathrm{CO}_{3}$ and indicated that the silicate anions increased while the carbonate anions decreased the strength of the AAS pastes. Recently, Yang et al. [2] used the combination of $\mathrm{Ca}(\mathrm{OH})_{2}$ and $\mathrm{Na}_{2} \mathrm{CO}_{3}$ to activate GGBS and found that the hydration products were calcium silicate hydrate $(\mathrm{C}-\mathrm{S}-\mathrm{H})$ gel, gehlenite hydrate $\left(\mathrm{C}_{2} \mathrm{ASH}_{8}\right)$, 
calcium aluminium hydrate $\left(\mathrm{C}_{4} \mathrm{AH}_{13}\right)$, and magnesium silicate hydrate $(\mathrm{M}-\mathrm{S}-\mathrm{H})$ gel. In terms of strength, the combination of $\mathrm{Ca}(\mathrm{OH})_{2}$ and $\mathrm{Na}_{2} \mathrm{CO}_{3}$ gave $\sim 20 \%$ increase over that using $\mathrm{Ca}(\mathrm{OH})_{2}$ alone.

Hard-burned $\mathrm{MgO}$ (calcined at $\sim 1000-1200{ }^{\circ} \mathrm{C}$ ) has been used as an expansive additive for PC-based concrete in large concrete dam construction in China for decades [15]. Reactive $\mathrm{MgO}$ is usually calcined at $700-1000{ }^{\circ} \mathrm{C}$ and has a higher reactivity than the hard-burned, as well as the dead-burned $\mathrm{MgO}$ produced $\geq 1400{ }^{\circ} \mathrm{C}$, which is usually present in PC. However, the physical and chemical properties of reactive $\mathrm{MgO}$ vary considerably, which are primarily governed by the source of the precursor and calcination history [16]. Recently, reactive $\mathrm{MgO}$ was found to be an alternative activator for GGBS, and gave higher strengths than $\mathrm{Ca}(\mathrm{OH})_{2}$ activated GGBS at $>28 \mathrm{~d}[17,18]$. The effect of reactive $\mathrm{MgO}$ in the AAS systems has also been investigated. Shen et al. [19] showed that the addition of $10 \%$ reactive $\mathrm{MgO}$ reduced the shrinkage of sodium silicate activated slag/fly ash (AAFS) cement by $\sim 50 \%$, and the shrinkage was only slightly higher than that of PC. Meanwhile, the compressive strengths up to $7 \mathrm{~d}$ were found to increase slightly while the $28 \mathrm{~d}$ strength remained unchanged. Jin et al. [20] studied the strength and drying shrinkage of reactive $\mathrm{MgO}$ modified sodium silicate activated GGBS pastes using two different reactive $\mathrm{MgO}$. They showed that $\mathrm{MgO}$ with high reactivity accelerated the early hydration of AAS and significantly decreased the drying shrinkage. Although $\mathrm{MgO}$ with medium reactivity had little effect on the early strength, it also decreased the drying shrinkage of AAS. Previous findings [18,20,21] showed that reactive $\mathrm{MgO}$ was mainly consumed by the reaction with GGBS to form hydrotalcite-like phases (M-A-H), which contributed to the strength gain and the shrinkage reduction.

This paper aims to investigate the suitability of combining reactive $\mathrm{MgO}$ and $\mathrm{Na}_{2} \mathrm{CO}_{3}$ for the activation of GGBS. The effect of two different reactive MgOs with very different reactivities on the performance of the reactive $\mathrm{MgO}$ and $\mathrm{Na}_{2} \mathrm{CO}_{3}$ activated GGBS pastes was investigated. The unconfined compressive strength and drying shrinkage of the pastes were measured at different curing ages. The hydration products and the microstructure were followed by X-ray diffraction (XRD), thermogravimetric analysis (TGA) and scanning electron microscopy (SEM). 


\section{Materials and Methods}

The GGBS used in this study, with a hydraulic index of 1.6 according to [22], was obtained from Hanson, UK. Two different reactive MgOs (from Richard Baker Harrison, UK) with different characteristics were used as the additive. Based on the characterisation in [23], the first was $\mathrm{MgO}_{\mathrm{H}}$, categorised as a highly reactive $\mathrm{MgO}$, which almost completed its hydration in one day, and the second was $\mathrm{MgO}_{\mathrm{M}}$, defined as $\mathrm{MgO}$ with medium reactivity, which continued to hydrate after one month. The chemical compositions of the GGBS and reactive $\mathrm{MgOs}$ are shown in Table $1 . \mathrm{Na}_{2} \mathrm{CO}_{3}$ solution was prepared the day before mixing by dissolving the sodium carbonate anhydrite powders (Fisher Scientific, technical grade) in a predetermined amount of deionised water.

The $\mathrm{Na}_{2} \mathrm{CO}_{3}$ dosage varied from $4 \%$ to $8 \%$ by weight of GGBS while reactive $\mathrm{MgO}$ content ranged from 5 to $10 \%$ by weight of GGBS. The mix compositions of all the paste samples are listed in Table 2 where $\mathrm{N}, \mathrm{H}$ and $\mathrm{M}$ refer to $\mathrm{Na}_{2} \mathrm{CO}_{3}, \mathrm{MgO}_{\mathrm{H}}$ and $\mathrm{MgO}_{\mathrm{M}}$ respectively, with the $\mathrm{Na}_{2} \mathrm{CO}_{3}$ and $\mathrm{MgO}$ content followed by each notation. The water to solid (including the slag, reactive $\mathrm{MgO}$ and $\mathrm{Na}_{2} \mathrm{CO}_{3}$ ) ratio was fixed at 0.32 . The $\mathrm{MgO}_{\mathrm{H}}$ was only added with $4 \% \mathrm{Na}_{2} \mathrm{CO}_{3}$ due to its large surface area causing significant decrease of workability as well as its high price. The reactive $\mathrm{MgO}$ powder was first mixed with the slag for 3 minutes in a bench-top mixer to achieve homogeneity to which the $\mathrm{Na}_{2} \mathrm{CO}_{3}$ solution was then added. After mixing for another $3 \mathrm{~min}$, the mix was cast into the cubic $(40 \times 40 \times 40 \mathrm{~mm})$ or prism $(40 \times 40 \times 160 \mathrm{~mm})$ moulds in two layers and hand-vibrated to eliminate the voids. The samples were then covered with cling film to avoid moisture loss. After 24 hours, the samples were demoulded carefully and the cubes were transferred into the water tank maintained at $21 \pm 2{ }^{\circ} \mathrm{C}$, while the prisms were stored at the temperature of $21 \pm 2{ }^{\circ} \mathrm{C}$ and relative humidity of $50 \pm 5 \%$.

The drying shrinkage measurement was performed using a CONTROLS electronic length comparator with an accuracy of $\pm 0.001 \mathrm{~mm}$ to determine the linear dimension variation of the prism specimen along the longitudinal axis. The first reading was recorded immediately after demoulding and the measurement was conducted in triplicate for each mix up to 90 days. The unconfined compressive strength (UCS) of the cubic samples, in triplicate, was determined according to [24] at the curing age 
of 1, 3, 7, 28 and 90 days. Then the crushed samples were ground and stored in acetone for 3 days to arrest the hydration and then vacuum dried for $\geq 3$ days followed by oven drying at $60{ }^{\circ} \mathrm{C}$ before microstructural analysis. The samples were then further ground to pass through a 75 micron sieve prior to XRD tests and TGA. XRD was carried out on a Siemens D5000 X-ray diffractometer using a scanning range from 5 to $55(2 \theta)$, with a scanning speed of 1 s/step and resolution of $0.05^{\circ} /$ step. TGA was conducted on duplicate samples on PerkinElmer STA6000 equipment from 40 to $800{ }^{\circ} \mathrm{C}$ with the increasing rate of $10{ }^{\circ} \mathrm{C} / \mathrm{min}$. The standard error between two samples was in general less than $5 \%$, so the average values were reported. SEM was performed on the JEOL 820 machine.

\section{Results and Discussion}

\subsection{Strength development}

Fig. 1 shows the UCS development of all the pastes in which it is apparent that the strength at $1 \mathrm{~d}$ increased significantly by the addition of $\mathrm{MgO}_{\mathrm{H}}$. At 7 and $28 \mathrm{~d}$, the UCS development was the same for $\mathrm{MgO}_{\mathrm{H}}$ based AAS, with $5 \% \mathrm{MgO}_{\mathrm{H}}$ addition showing the highest strength. However, the strength gain almost stopped at $28 \mathrm{~d}$ and approximately the same strength ( 45-50 MPa) was obtained for the reference mix and the modified mixes at $90 \mathrm{~d}$ (Fig.1a). On the other hand, the strength was almost negligible at $1 \mathrm{~d}$ with $\mathrm{MgO}_{\mathrm{M}}$ addition regardless of the $\mathrm{Na}_{2} \mathrm{CO}_{3}$ content. After $90 \mathrm{~d}$ of water curing, $4 \%$ $\mathrm{Na}_{2} \mathrm{CO}_{3}$ with $5 \% \mathrm{MgO}_{\mathrm{M}}$ content showed the highest strength and the reached $\sim 65 \mathrm{MPa}$, which was $\sim 45 \%$ higher than the reference mix (Fig. 1b). Nevertheless, higher dosages of $\mathrm{MgO}_{\mathrm{M}}$ slightly decreased the strength at $28 \mathrm{~d}$. At $6 \% \mathrm{Na}_{2} \mathrm{CO}_{3}$ content, it was found that the addition of $\mathrm{MgO}_{\mathrm{M}}$ did not increase the strength too much in the early ages $(\leq 3 \mathrm{~d})$. At 7 and $28 \mathrm{~d}, 5-7.5 \% \mathrm{MgO}_{\mathrm{M}}$ addition slightly increased the strength while $10 \% \mathrm{MgO}_{\mathrm{M}}$ reduced the strength compared to the reference mix. At $90 \mathrm{~d}$, the mix with $5 \% \mathrm{MgO}_{\mathrm{M}}$ showed significantly higher strength than the other mixes (Fig. 1c). At $8 \%$ $\mathrm{Na}_{2} \mathrm{CO}_{3}$ content, no benefit of adding reactive $\mathrm{MgO}$ was observed in terms of strength during the first $28 \mathrm{~d}$ of curing. In addition, when the content of $\mathrm{MgO}_{\mathrm{M}}$ was $\geq 5 \%$, the strength decreased by $\sim 12 \%$ compared to sample N8 (without $\mathrm{MgO}$ ) at $90 \mathrm{~d}$ (Fig. 1d). Therefore, it was concluded that $5 \%$ of reactive $\mathrm{MgO}$ was the optimum content and the effect was dependent on the $\mathrm{MgO}$ type and the content of $\mathrm{Na}_{2} \mathrm{CO}_{3}$. At $4 \%$ of $\mathrm{Na}_{2} \mathrm{CO}_{3}$ concentration, $5 \%$ of $\mathrm{MgO}_{\mathrm{H}}$ could effectively increase the early 
strength of $\mathrm{Na}_{2} \mathrm{CO}_{3}$ activated GGBS while the long term strength was not affected. On the other hand, $5 \%$ of $\mathrm{MgO}_{\mathrm{M}}$ helped to increase the strength at later ages ( $90 \mathrm{~d}$ ), but gave no benefits to the early strength. Increasing the $\mathrm{Na}_{2} \mathrm{CO}_{3}$ content obscured the effect of reactive $\mathrm{MgO}$.

\subsection{Drying shrinkage}

Fig. 2 shows the drying shrinkage values up to $90 \mathrm{~d}$ for the $4 \% \mathrm{Na}_{2} \mathrm{CO}_{3}$ activated GGBS pastes with the addition of $5 \%$ and $10 \%$ of two reactive MgOs. It was found that the shrinkage of the pastes containing $\mathrm{MgO}_{\mathrm{M}}$ was close to the reference (N4) during the first week. Afterwards, the shrinkage of the paste with $5 \% \mathrm{MgO}_{\mathrm{M}}$ only increased slightly from $28 \mathrm{~d}$ to $90 \mathrm{~d}$, showing a final shrinkage decreased by $\sim 13 \%$ than the reference (N4). Meanwhile, $10 \%$ of $\mathrm{MgO}_{\mathrm{M}}$ increased the shrinkage by $\sim 10 \%$. On the other hand, $\mathrm{MgO}_{\mathrm{H}}$ was much more effective in reducing the shrinkage of the AAS paste especially at early ages. It was observed that the shrinkage of the paste with $5 \% \mathrm{MgO}_{\mathrm{H}}$ addition (N4H5) showed 3 times less shrinkage than the reference at $1 \mathrm{~d}$ and still exhibited $50 \%$ less at $7 \mathrm{~d}$. Finally, $\sim 17 \%$ decrease in shrinkage was achieved at $90 \mathrm{~d}$. Increasing the content of $\mathrm{MgO}_{\mathrm{H}}$ to $10 \%$ slightly increased the shrinkage, though it was still much lower than the reference showing $\sim 10 \%$ less shrinkage than the reference at $90 \mathrm{~d}$.

The effect of the content of $\mathrm{Na}_{2} \mathrm{CO}_{3}$ and $\mathrm{MgO}_{\mathrm{M}}$ on the drying shrinkage is illustrated in Fig. 3. It was apparent that increasing the $\mathrm{Na}_{2} \mathrm{CO}_{3}$ content from $4 \%$ to $6 \%$ significantly decreased $(\sim 53 \%)$ the shrinkage of the pastes, while no difference was detected when it increased from $6 \%$ to $8 \%$. The addition of $5 \%$ of $\mathrm{MgO}_{\mathrm{M}}$ showed the lowest shrinkage regardless of the $\mathrm{Na}_{2} \mathrm{CO}_{3}$ content, which is consistent with the strength results that $5 \%$ is the optimum $\mathrm{MgO}$ content. It should be noted that although no strength benefit was observed by adding $\mathrm{MgO}_{\mathrm{M}}$ at $8 \% \mathrm{Na}_{2} \mathrm{CO}_{3}$ content (Fig. 1d), the drying shrinkage decreased by $\sim 30 \%$ at $28 \mathrm{~d}$.

\subsection{XRD results}

The XRD patterns of the reactive $\mathrm{MgO}$ and $\mathrm{Na}_{2} \mathrm{CO}_{3}$ activated GGBS pastes cured for $28 \mathrm{~d}$ are shown in Fig. 4. Comparing the effects of the two reactive $\mathrm{MgOs}, \mathrm{MgO}_{\mathrm{H}}$ reacted much faster with slag to 
produce more hydrotalcite-like phases which was indicated by the increased strongest characteristic peak of $\mathrm{Ht}$ at $2 \theta$ of $\sim 11.7^{\circ}$ (Fig. $4 \mathrm{a}$ ), which increased with the increase of $\mathrm{MgO}$ content. Much higher peak of $\mathrm{MgO}$ was identified in pastes containing $\mathrm{MgO}_{\mathrm{M}}$ indicating higher content of unhydrated $\mathrm{MgO}$ (indicated by the higher peak at $2 \theta$ of $42.9^{\circ}$ ) due to its lower reactivity compared to the pastes with $\mathrm{MgO}_{\mathrm{H}}$. It should be noted that there was no brucite detected in all the pastes regardless of the $\mathrm{MgO}$ type and content $(\leq 10 \mathrm{wt} \%)$, which agreed well with previous studies [20,21], although a minor content of brucite out of the XRD detection limit could exist. A small peak for $\mathrm{Na}_{2} \mathrm{CO}_{3}$ at $2 \theta$ of $35^{\circ}$ was detected suggesting that both the activators were not fully consumed by GGBS at $28 \mathrm{~d}$. In addition, characteristic peak for calcium sodium carbonate hydrate at $2 \theta$ of $47.7^{\circ}$ was found. Various peaks for calcite were denoted in the patterns, which could be due to the carbonation of portlandite or C-S-H gel during the sample preparation and curing stages. It could also come from the causticisation of $\mathrm{Na}_{2} \mathrm{CO}_{3}$ as suggested in [25]:

$\mathrm{Na}_{2} \mathrm{CO}_{3}+\mathrm{Ca}(\mathrm{OH})_{2}=2 \mathrm{NaOH}+\mathrm{CaCO}_{3}$

Consequently, as it can be seen from the XRD curves, the peaks for calcite increased with the increase of $\mathrm{Na}_{2} \mathrm{CO}_{3}$ concentration.

Increasing the $\mathrm{Na}_{2} \mathrm{CO}_{3}$ content was found to increase the intensities of all the hydration products as illustrated in Fig. 4b, which indicates the enhancement of the slag hydration degrees and consequently higher strength. In addition, gehlenite hydrate as the minor hydration product was also observed, agreeing with [2].

The role of calcite played in the pastes is in analogy with hydrotalcite-like phases. Previous studies $[10,26]$ on the role of limestone in slag cement indicated that calcite powder could refine the pore structure and improve the early strength. Therefore, an optimum content of reactive $\mathrm{MgO}$ (5\% in this study) existed when the quantities of hydrotalcite-like phases and calcite were sufficient to give the lowest porosity and highest strength while higher contents would result in excess voluminous phases (i.e., hydrotalcite-like phases and/or brucite) and hence micro-cracks in the matrix leading to reduced strength. 


\subsection{TGA results}

The TG and first derivative of TG (DTG) curves of the pastes cured for $28 \mathrm{~d}$ are shown in Fig. 5. The DTG curves were divided into four ranges:

1. At temperature up to $250{ }^{\circ} \mathrm{C}$, this mainly involves the dehydration of C-S-H. In addition, MS-H gel could also form by the reaction between $\mathrm{MgO}$ and dissolved $\mathrm{SiO}_{2}$, and loses its water between $80-200{ }^{\circ} \mathrm{C}$.

2. The temperature range of $250-450{ }^{\circ} \mathrm{C}$ includes mainly the decomposition of hydrotalcite-like phases, since brucite was found to be totally consumed by the reaction with slag from the XRD analysis.

3. The small shoulder at around $450-500{ }^{\circ} \mathrm{C}$ was attributed to the dehydration of portlandite.

4. The temperature range between $500{ }^{\circ} \mathrm{C}$ and $800{ }^{\circ} \mathrm{C}$ is the decomposition range of various carbonate-containing phases including magnesium carbonate, calcium carbonate, calcium sodium carbonate, sodium carbonate, and hydrotalcite-like phases.

The first two major weight losses $\left(\Delta \mathrm{m}_{1}\right.$ and $\left.\Delta \mathrm{m}_{2}\right)$ and the total weight loss $\left(\Delta \mathrm{m}_{\mathrm{t}}\right)$ were calculated by combining the TG and DTG curves and the results are shown in Table 3. It is apparent that with the increase of reactive $\mathrm{MgO}$ content, the total weight loss (i.e., chemically bound water content, $\mathrm{CBW}$ ) increased. The effect of $\mathrm{MgO}_{\mathrm{H}}$ was much greater than the $\mathrm{MgO}_{\mathrm{M}}$, due to the larger quantities of the CS-H and hydrotalcite-like phases formed (indicated by the increase of $\Delta \mathrm{m}_{1}$ and $\Delta \mathrm{m}_{2}$ ) and the higher density of water in hydrotalcite-like phases. It also showed that the quantities of $\mathrm{C}-\mathrm{S}-\mathrm{H}$ and hydrotalcite-like phases increased much more significantly in pastes with $4 \% \mathrm{Na}_{2} \mathrm{CO}_{3}$ than those with $8 \% \mathrm{Na}_{2} \mathrm{CO}_{3}$, which was consistent with the strength results that the addition of reactive $\mathrm{MgO}$ was more effective with lower concentration of $\mathrm{Na}_{2} \mathrm{CO}_{3}$. In addition, the content of the carbonates was significantly higher in the samples with $8 \% \mathrm{Na}_{2} \mathrm{CO}_{3}$ as indicated by the weight loss at $500-800{ }^{\circ} \mathrm{C}$.

To elucidate the effect of different reactive MgOs, the relationship between CBW and UCS of the paste with two types of $\mathrm{MgOs}$ and $4 \% \mathrm{Na}_{2} \mathrm{CO}_{3}$ was plotted in Fig. 6. For $\mathrm{MgO}_{\mathrm{M}}$, there was a good linear relationship between CBW (as well as the $\mathrm{MgO}_{\mathrm{M}}$ content) and UCS at $3 \mathrm{~d}$ indicating that the 
$\mathrm{MgO}$ with lower reactivity led to a slower increase of hydration products. These newly formed products caused a gradual pore filing and consequently increased the strength of the pastes. At $28 \mathrm{~d}$, with the increase of CBW (and $\mathrm{MgO}_{\mathrm{M}}$ content), UCS increased up to $\mathrm{MgO}_{\mathrm{M}}$ content of $5 \%$ while it decreased notably when $\mathrm{MgO}_{\mathrm{M}}$ content reached $10 \%$, suggesting that although the hydration products increased, the strength decreased, which could be due to the deterioration of the pore structure by excess hydrotalcite-like phases or a minor content of brucite that cannot be detected in XRD [20]. On the other hand, when highly reactive $\mathrm{MgO}\left(\mathrm{MgO}_{\mathrm{H}}\right)$ was used, this over filling effect was manifested at $3 \mathrm{~d}$ and continued till $28 \mathrm{~d}$ since it resulted in a much faster increase of hydration degree and the content of hydration products.

\subsection{Microstructure}

Fig. 7 shows typical SEM images of selected pastes at $3 \mathrm{~d}$ of curing. The early hydration product was mainly reticulated C-S-H (see Fig. 7a inset) covering the slag particles for the N4 and N4M5 samples at $3 \mathrm{~d}$ (Fig. 7a and c), resembling these observed in sodium silicate activated GGBS at early ages [20]. When $5 \%$ of highly reactive $\mathrm{MgO}(\mathrm{N} 4 \mathrm{H} 5)$ or more $\mathrm{Na}_{2} \mathrm{CO}_{3}(\mathrm{~N} 8)$ was used, relatively dense $\mathrm{C}-\mathrm{S}-\mathrm{H}$ gel was formed and showed a much less porosity than the former two (Fig. $7 \mathrm{~b}$ and d), which were consistent with their strength and TGA results. The gels have occupied the spaces that were initially filled with water and generated a more compact microstructure, which further led to increased strength and more chemically bound water as presented above. Small crumbles in the N8 sample could be assigned to the excessive $\mathrm{Na}_{2} \mathrm{CO}_{3}$ or the calcite formed as explained in XRD section. It was concluded that $\mathrm{MgO}_{\mathrm{H}}$ accelerated the early age hydration of the slag while $\mathrm{MgO}_{\mathrm{M}}$ had almost no effect. There could be two effects by the addition of highly reactive $\mathrm{MgO}$ : (i) the quick hydration of $\mathrm{MgO}_{\mathrm{H}}$ resulting in much more hydration products that can fill the pores more effectively and (ii) the fast heat release during the dissolution process of $\mathrm{MgO}$ leading to higher dissolution rate of GGBS and also higher reaction rate among the cement components. At $28 \mathrm{~d}$, all mixes formed dense microstructure consisting primarily of $\mathrm{C}-\mathrm{S}-\mathrm{H}$ gels (Figure 8) and the other hydration products probably had no distinctive morphology and intermixed with the gels, which made them hard to identify. It should be noted that small cracks were visible in N4H5 sample, which could explain why its strength stopped to 
gain from 28 to $90 \mathrm{~d}$. Although hydration was still progressing as indicated by the TGA results, the cracks formed initially would expand and reduce the strength.

\section{Conclusions}

The mechanical and drying shrinkage properties of reactive $\mathrm{MgO}$ and $\mathrm{Na}_{2} \mathrm{CO}_{3}$ activated GGBS pastes were investigated in order to evaluate the suitability of combining reactive $\mathrm{MgO}$ and $\mathrm{Na}_{2} \mathrm{CO}_{3}$ as a sustainable activator for GGBS. The following conclusions can be drawn based on the experimental results obtained above:

1. It was found that an optimum content of reactive $\mathrm{MgO}$ (i.e., $5 \%$ by weight of the slag) existed regardless of the $\mathrm{MgO}$ type and $\mathrm{Na}_{2} \mathrm{CO}_{3}$ content. The effect of reactive $\mathrm{MgO}$ was more significant with low $\mathrm{Na}_{2} \mathrm{CO}_{3}$ content (4\%), while at $8 \% \mathrm{Na}_{2} \mathrm{CO}_{3}$ content, even with the optimum reactive $\mathrm{MgO}$ addition, the strength was almost the same as the reference.

2. $\mathrm{MgO}$ with high reactivity ( $10 \mathrm{~s})$ increased the early strength of $\mathrm{Na}_{2} \mathrm{CO}_{3}$ activated GGBS significantly while $\mathrm{MgO}$ with medium reactivity ( 100 s) had no observable effect. However, the long term strength of pastes using highly reactive $\mathrm{MgO}$ was the same as the reference, while the addition of $\mathrm{MgO}$ with medium reactivity helped to increase the 90-d strength by $\sim 45 \%$.

3. In terms of drying shrinkage, increasing the $\mathrm{Na}_{2} \mathrm{CO}_{3}$ content from $4 \%$ to $6 \%$ caused a remarkable decrease of drying shrinkage while increasing it from $6 \%$ to $8 \%$ had negligible effect. Adding 5\% reactive $\mathrm{MgO}$ can effectively reduce the drying shrinkage of $\mathrm{Na}_{2} \mathrm{CO}_{3}$ activated GGBS pastes regardless of $\mathrm{Na}_{2} \mathrm{CO}_{3}$ content.

4. XRD and TGA revealed that the major hydration products are C-S-H gel and hydrotalcite-like phases, with gehlenite hydrate as the minor phase. Both the $\mathrm{MgO}$ and $\mathrm{Na}_{2} \mathrm{CO}_{3}$ were not fully consumed at $28 \mathrm{~d}$. In addition, there was a large quantity of calcite formed especially in $8 \%$ $\mathrm{Na}_{2} \mathrm{CO}_{3}$ pastes probably due to causticisation.

The combination of reactive $\mathrm{MgO}$ and $\mathrm{Na}_{2} \mathrm{CO}_{3}$ could serve as a promising sustainable activator for slags compared to the conventional caustic alkali hydroxides or silicates. In addition, considering the 
low-shrinkage of $\mathrm{Na}_{2} \mathrm{CO}_{3}$ activated slag [6] and the shrinkage-reducing effect of $\mathrm{MgO}$ [15], this combination could probably generate AAS concrete with low drying shrinkage, facilitating the spread of AAS concrete. However, further research is needed to study other performance of this kind of AAS such as the setting time, rheology, and durability.

\section{Acknowledgement}

The first author is grateful to Cambridge Trust and China Scholarship Council (CSC) for sponsoring his PhD studentship.

\section{References}

[1] Metz B, Davidson O, Coninck H de, Loos M, Meyer L. IPCC Special Report on Carbon dioxide Capture and Storage. 2005.

[2] Yang K-H, Cho A-R, Song J-K, Nam S-H. Hydration products and strength development of calcium hydroxide-based alkali-activated slag mortars. Constr Build Mater 2012;29:410-9.

[3] Duxson P, Provis JL, Lukey GC, van Deventer JSJ. The role of inorganic polymer technology in the development of "green concrete." Cem Concr Res 2007;37:1590-7.

[4] Song S, Sohn D, Jennings H. Hydration of alkali-activated ground granulated blast furnace slag. J Mater Sci 2000;35:249-57.

[5] Rashad AM, Bai Y, Basheer PAM, Milestone NB, Collier NC. Hydration and properties of sodium sulfate activated slag. Cem Concr Compos 2012.

[6] Duran Atiş C, Bilim C, Çelik Ö, Karahan O. Influence of activator on the strength and drying shrinkage of alkali-activated slag mortar. Constr Build Mater 2009;23:548-55.

[7] Fernández-Jiménez A. Alkali-activated slag mortars Mechanical strength behaviour. Cem Concr Res 1999;29:1313-21.

[8] Kostick DS. Soda Ash: Statistics and Information. U.S. Geological Survey. 2013.

[9] Fernández-Jiménez A, Puertas F. Effect of activator mix on the hydration and strength behaviour of alkali-activated slag cements. Adv Cem Res 2003;15:129-36.

[10] Wang SDS, Scrivener KLK, Pratt P. Factors affecting the strength of alkali-activated slag. Cem Concr Res 1994;24:1033-43.

[11] Sakulich AR, Anderson E, Schauer C, Barsoum MW. Mechanical and microstructural characterization of an alkali-activated slag/limestone fine aggregate concrete. Constr Build Mater 2009;23:2951-7. 
[12] Andersson R, Gram HE. Properties of alkali-activated slag concrete. Nord Concr Res 1987;6:7-18.

[13] Collins F, Sanjayan JG. Early Age Strength and Workability of Slag Pastes Activated by $\mathrm{NaOH}$ and Na2CO3. Cem Concr Res 1998;28:655-64.

[14] Li Y, Sun Y. Preliminary study on combined-alkali-slag paste materials. Cem Concr Res 2000;30:963-6.

[15] Lou Z, Ye Q, Chen H, Wang Y, Shen J, Lou Z, et al. Hydration of MgO in clinker and its expansive property. J CHINESE Ceram Soc 1998;26:430-6.

[16] Shand MA. The Chemistry and Technology of Magnesia. Hoboken, New Jersey: John Wiley \& Sons, Ltd.; 2006.

[17] Yi Y, Liska M, Al-Tabbaa A. Properties and microstructure of GGBS-MgO pastes. Adv Cem Res 2014; 26:114-22.

[18] Jin F, Gu K, Al-Tabbaa A. Strength and hydration properties of reactive $\mathrm{MgO}$-activated ground granulated blastfurnace slag paste. Cem Concr Compos 2014 (Accepted).

[19] Shen W, Wang Y, Zhang T, Zhou M, Li J, Cui X. Magnesia modification of alkali-activated slag fly ash cement. J Wuhan Univ Technol Sci Ed 2011;26:121-5.

[20] Jin F, Gu K, Al-Tabbaa A. Strength and drying shrinkage of reactive $\mathrm{MgO}$ modified alkaliactivated slag paste. Constr Build Mater 2014;51:395-404.

[21] Jin F, Gu K, Abdollahzadeh A, Al-Tabbaa A. Effect of different reactive MgOs on the hydration of MgO-activated ground granulated blastfurnace slag paste. J Mater Civ Eng 2013.

[22] Mantel DG. Investigation into the hydraulic activity of five granulated blast furnace slags with eight different Portland cements. ACI Mater J 1994;91.

[23] Jin F, Al-Tabbaa A. Characterisation of different commercial reactive magnesia. ICE Adv Cem Res 2014;26:101-13.

[24] British Standards BS EN 196-1. Methods of testing cement-Part 1: Determination of strength. 2005.

[25] Zsako J, Hints M. Use of thermal analysis in the study of sodium carbonate causticization by means of dolomitic lime. J Therm Anal Calorim 1998;53:323-31.

[26] Mun KJ, So SY, Soh YS. The effect of slaked lime, anhydrous gypsum and limestone powder on properties of blast furnace slag cement mortar and concrete. Constr Build Mater 2007;21:1576-82. 


\section{Figure Captions:}

Figure $1 \mathrm{UCS}$ development of reactive $\mathrm{MgO}$ and $\mathrm{Na}_{2} \mathrm{CO}_{3}$ activated GGBS pastes (a) $4 \% \mathrm{Na}_{2} \mathrm{CO}_{3}+$ $\mathrm{MgO}_{\mathrm{M}}$; (b) $4 \% \mathrm{Na}_{2} \mathrm{CO}_{3}+\mathrm{MgO}_{\mathrm{H}}$; (c) $6 \% \mathrm{Na}_{2} \mathrm{CO}_{3}+\mathrm{MgO}_{\mathrm{M}} ; 8 \% \mathrm{Na}_{2} \mathrm{CO}_{3}+\mathrm{MgO}_{\mathrm{M}}$

Figure 2 Drying shrinkage of $4 \% \mathrm{Na}_{2} \mathrm{CO}_{3}+\mathrm{MgO}_{\mathrm{H}}$ activated GGBS pastes

Figure 3 Drying shrinkage of GGBS pastes activated by $\mathrm{Na}_{2} \mathrm{CO}_{3}+\mathrm{MgO}_{\mathrm{M}}$

Figure 4 XRD patterns of reactive $\mathrm{MgO}$ and $\mathrm{Na}_{2} \mathrm{CO}_{3}$ activated GGBS pastes at $28 \mathrm{~d}$ (a) two types of $\mathrm{MgO}$ with $4 \% \mathrm{Na}_{2} \mathrm{CO}_{3}$; (b) $\mathrm{MgO}_{\mathrm{M}}$ with $8 \% \mathrm{Na}_{2} \mathrm{CO}_{3}$. Notations: C: C-S-H, CC: calcite, $\mathrm{CN}$ : sodium calcium carbonate, G: gehlenite hydrate, Ht: hydrotalcite-like phases, $\mathrm{N}$ : sodium carbonate.

Figure 5 TG/DTG curves of reactive $\mathrm{MgO}$ and $\mathrm{Na}_{2} \mathrm{CO}_{3}$ activated GGBS pastes at $28 \mathrm{~d}$ (a) and (b) TG and DTG of two types of $\mathrm{MgO}$ with $4 \% \mathrm{Na}_{2} \mathrm{CO}_{3}$; (c) and (d) TG and DTG of $\mathrm{MgO}_{\mathrm{M}}$ with $8 \% \mathrm{Na}_{2} \mathrm{CO}_{3}$

Figure 6 Relationship between CBW and UCS of the pastes with different types and contents of MgOs and $4 \%$ of $\mathrm{Na}_{2} \mathrm{CO}_{3}$

Figure $7 \mathrm{SEM}$ pictures of reactive $\mathrm{MgO}$ and $\mathrm{Na}_{2} \mathrm{CO}_{3}$ activated GGBS pastes at $3 \mathrm{~d}$ (a) N4, (b) N4H5, (c) N4M5, and (d) N8

Figure $8 \mathrm{SEM}$ pictures of reactive $\mathrm{MgO}$ modified $\mathrm{Na}_{2} \mathrm{CO}_{3}$ activated GGBS pastes at $28 \mathrm{~d}$ (a) $\mathrm{N} 4$, (b) N4H5, (c) N4M5, and (d) N8 
Table 1 Physico-chemical properties of the raw materials used in this study

\begin{tabular}{|c|c|c|c|c|}
\hline \multicolumn{2}{|c|}{ Label } & $\mathrm{MgO}_{\mathrm{H}}$ & $\mathrm{MgO}_{\mathrm{M}}$ & GGBS \\
\hline \multirow{10}{*}{$\begin{array}{c}\text { Chemical } \\
\text { composition (\%) }\end{array}$} & $\mathrm{MgO}$ & 97.5 & 93.2 & 8 \\
\hline & $\mathrm{CaO}$ & 1 & 0.9 & 40 \\
\hline & $\mathrm{Cl}$ & 0.2 & - & - \\
\hline & $\mathrm{SiO}_{2}$ & 1 & 0.9 & 37 \\
\hline & $\mathrm{Fe}_{2} \mathrm{O}_{3}$ & 0.035 & 0.5 & - \\
\hline & $\mathrm{Al}_{2} \mathrm{O}_{3}$ & - & 0.22 & 13 \\
\hline & $\mathrm{Mn}$ & 0.006 & - & - \\
\hline & $\mathrm{Na}_{2} \mathrm{O}$ & - & - & 0.3 \\
\hline & $\mathrm{K}_{2} \mathrm{O}$ & - & - & 0.6 \\
\hline & $\mathrm{SO}_{3}$ & 0.85 & - & 2.5 \\
\hline \multicolumn{2}{|c|}{ Reactivity* $(\mathrm{s})$} & 10 & 100 & - \\
\hline \multicolumn{2}{|c|}{ Specific surface area $\left(\mathrm{m}^{2} / \mathrm{g}\right)$} & 110.82 & 9.005 & 0.493 \\
\hline
\end{tabular}

*Measured according to the acetic acid test [16] 
Table 2 Mix compositions with various sodium carbonate and reactive $\mathrm{MgO}$ contents (by weight of GGBS) and two types of reactive $\mathrm{MgOs}$

\begin{tabular}{|c|c|c|c|}
\hline $\mathrm{Na}_{2} \mathrm{CO}_{3}$ content $/ \%$ & Paste notation & $\mathrm{MgO}_{\mathrm{H}}$ content $/ \%$ & $\mathrm{MgO}_{\mathrm{M}}$ content $/ \%$ \\
\hline \multirow[t]{7}{*}{ 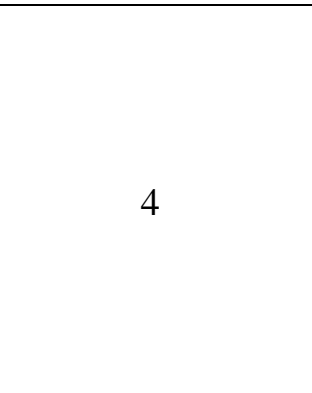 } & $\mathrm{N} 4$ & - & - \\
\hline & N4H5 & 5 & - \\
\hline & N4H7.5 & 7.5 & - \\
\hline & N4H10 & 10 & - \\
\hline & N4M5 & - & 5 \\
\hline & N4M7.5 & - & 7.5 \\
\hline & N4M10 & - & 10 \\
\hline \multirow{4}{*}{6} & N6 & - & - \\
\hline & N6M5 & - & 5 \\
\hline & N6M7.5 & - & 7.5 \\
\hline & N6M10 & - & 10 \\
\hline \multirow{4}{*}{8} & N8 & - & - \\
\hline & N8M5 & - & 5 \\
\hline & N8M7.5 & - & 7.5 \\
\hline & N8M10 & - & 10 \\
\hline
\end{tabular}


Table 3 Weight losses in percentage calculated from TG/DTG curves

\begin{tabular}{ccccccc}
\hline \multirow{2}{*}{$\begin{array}{c}\text { Paste } \\
\text { denotation }\end{array}$} & \multicolumn{6}{c}{ Curing age } \\
\cline { 2 - 7 } & $\begin{array}{c}\Delta \mathrm{m}_{1} \\
\left(<250{ }^{\circ} \mathrm{C}\right)\end{array}$ & $\begin{array}{c}\Delta \mathrm{m}_{2}(250- \\
\left.450{ }^{\circ} \mathrm{C}\right)\end{array}$ & $\begin{array}{c}\Delta \mathrm{m}_{\mathrm{t}}(40- \\
\left.800{ }^{\circ} \mathrm{C}\right)\end{array}$ & $\begin{array}{c}\Delta \mathrm{m}_{1} \\
\left(<250{ }^{\circ} \mathrm{C}\right)\end{array}$ & $\begin{array}{c}\Delta \mathrm{m}_{2}(250- \\
\left.450{ }^{\circ} \mathrm{C}\right)\end{array}$ & $\begin{array}{c}\Delta \mathrm{m}_{\mathrm{t}}(40- \\
\left.800{ }^{\circ} \mathrm{C}\right)\end{array}$ \\
\hline $\mathrm{N} 4$ & 2.79 & 3.42 & 8.33 & 3.85 & 1.85 & 8.94 \\
\hline $\mathrm{N} 4 \mathrm{M} 5$ & 3.19 & 3.13 & 8.67 & 4.40 & 2.38 & 9.69 \\
\hline $\mathrm{N} 4 \mathrm{M} 10$ & 3.24 & 4.73 & 10.60 & 5.06 & 2.73 & 10.67 \\
\hline $\mathrm{N} 4 \mathrm{H} 5$ & 5.44 & 4.96 & 13.68 & 5.98 & 4.31 & 14.20 \\
\hline $\mathrm{N} 4 \mathrm{H} 10$ & 5.96 & 5.88 & 15.84 & 7.47 & 5.68 & 17.08 \\
\hline $\mathrm{N} 8$ & 4.75 & 4.29 & 13.87 & 6.32 & 2.83 & 13.92 \\
\hline $\mathrm{N} 8 \mathrm{M} 5$ & 5.04 & 4.69 & 14.22 & 6.61 & 3.45 & 14.71 \\
\hline $\mathrm{N} 8 \mathrm{M} 10$ & 4.42 & 4.17 & 12.72 & 6.71 & 3.53 & 15.17 \\
\hline
\end{tabular}



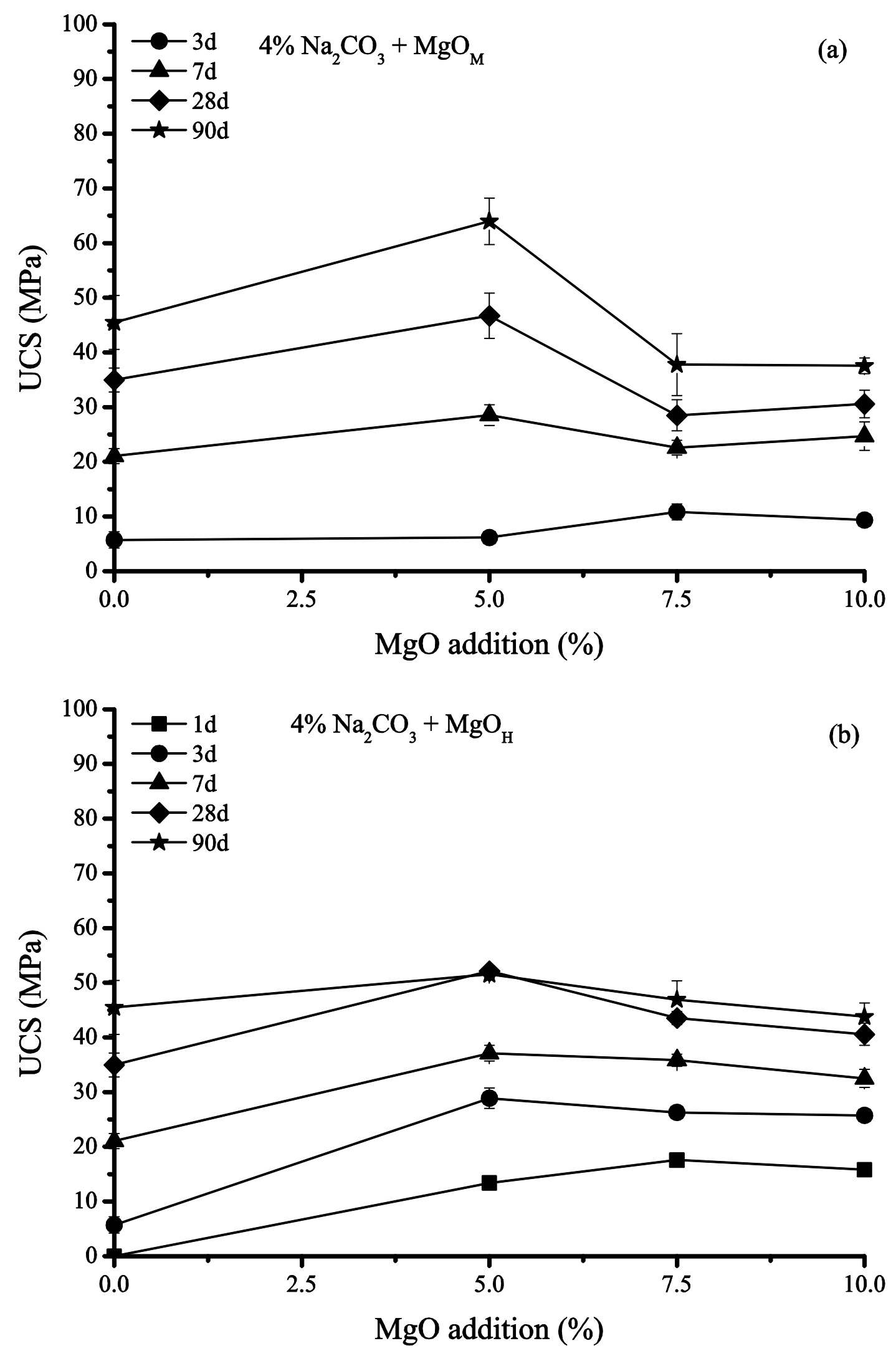

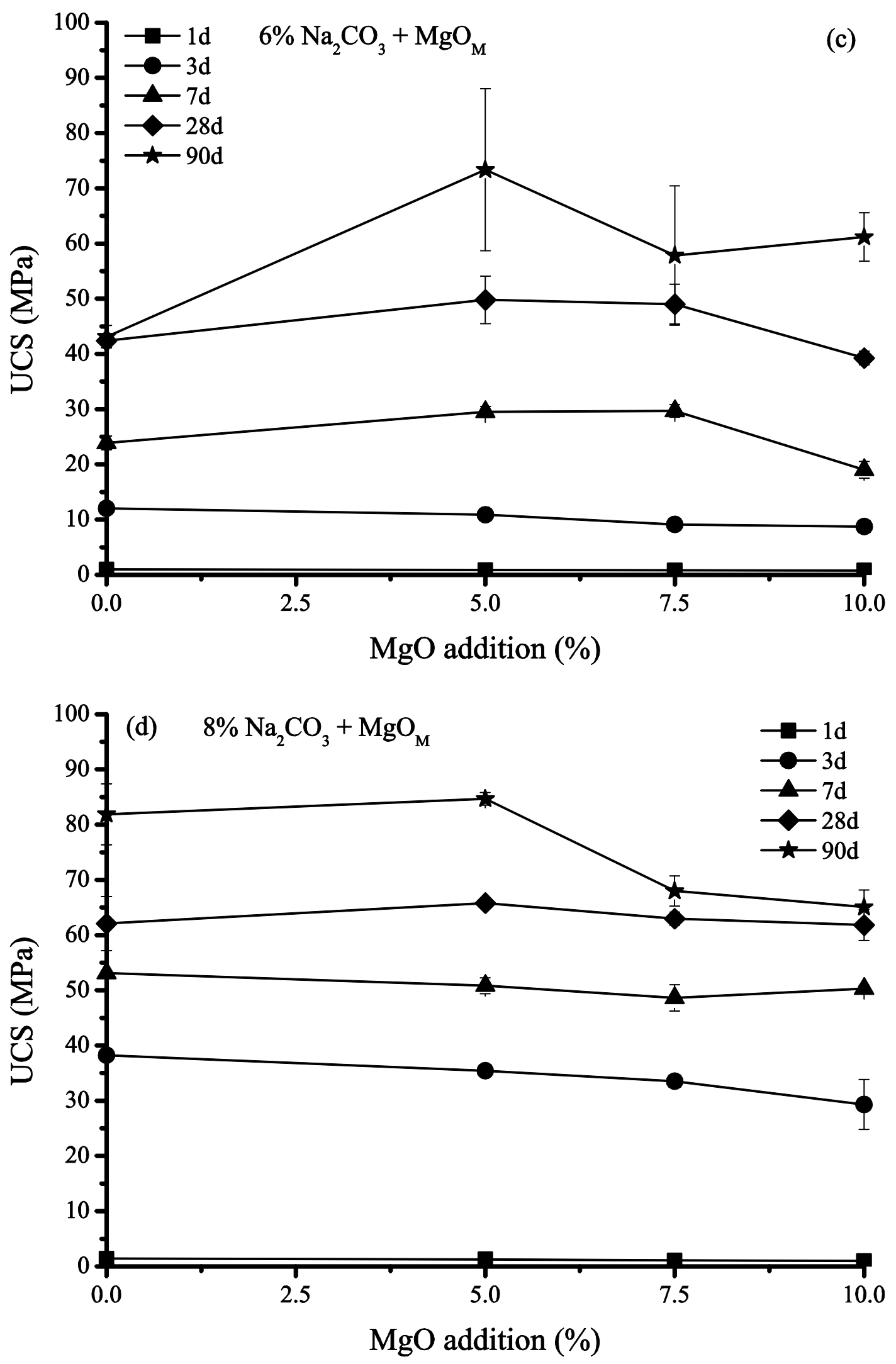

Fig. 1 


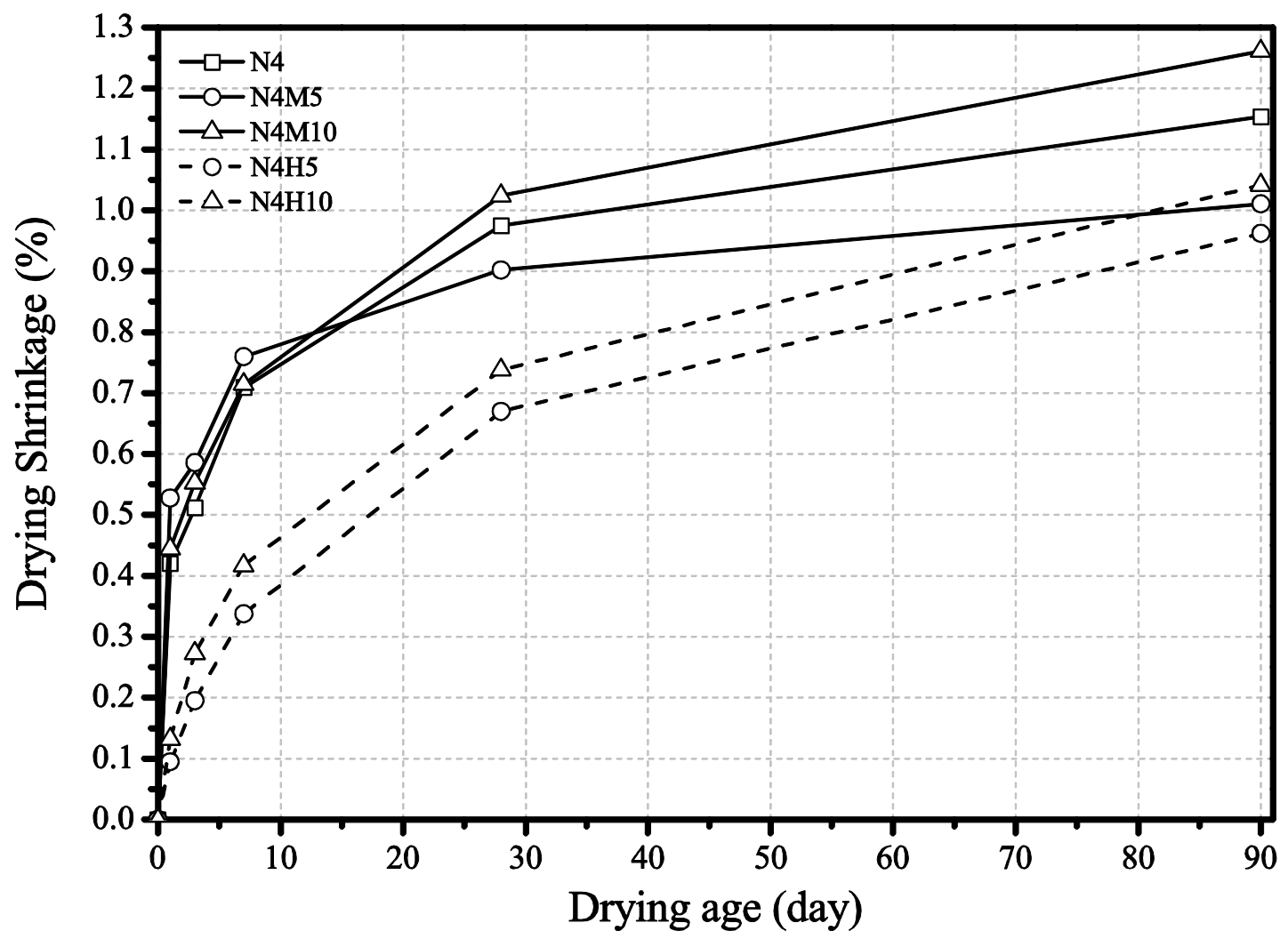

Fig. 2

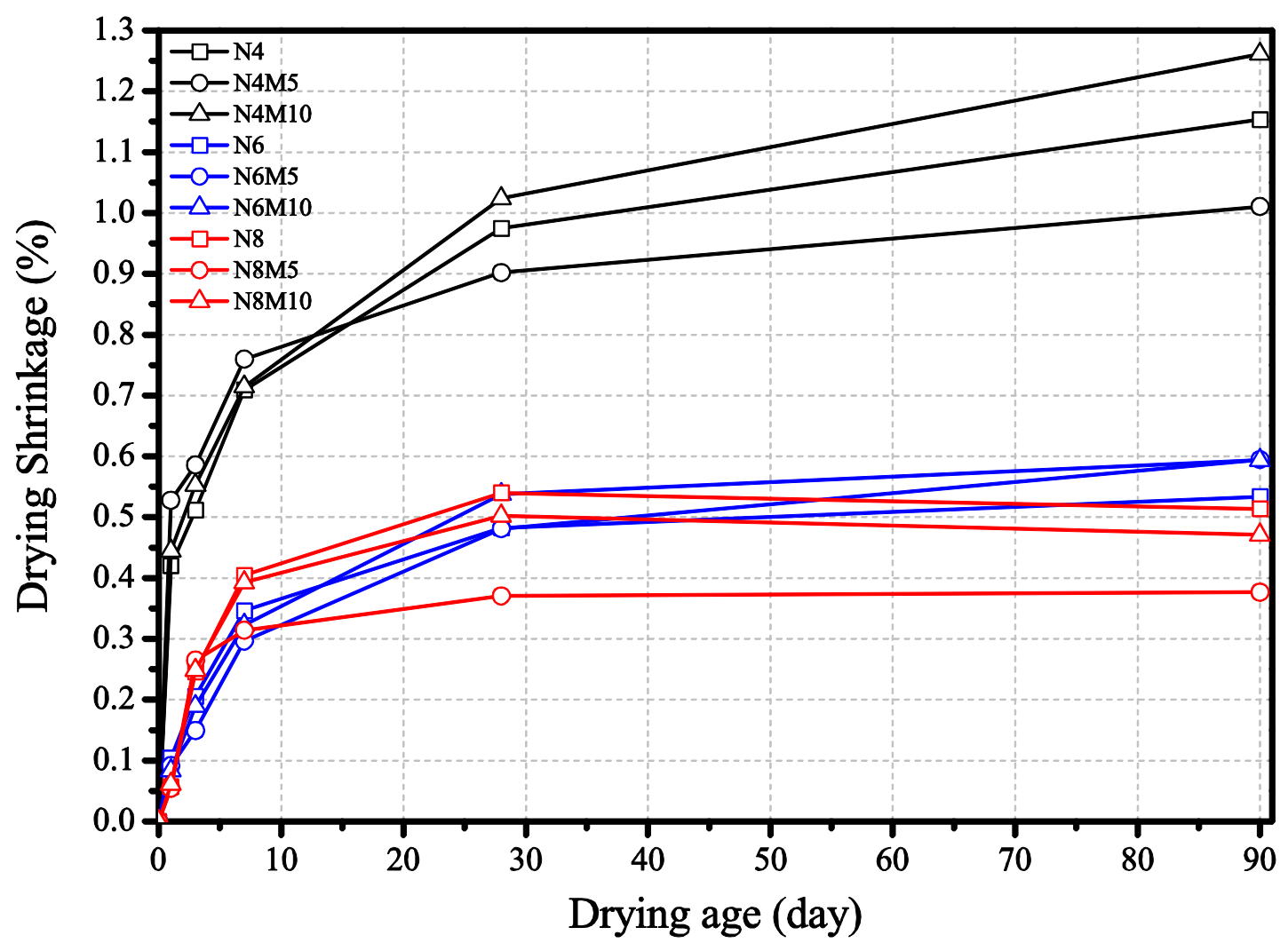

Fig.3 

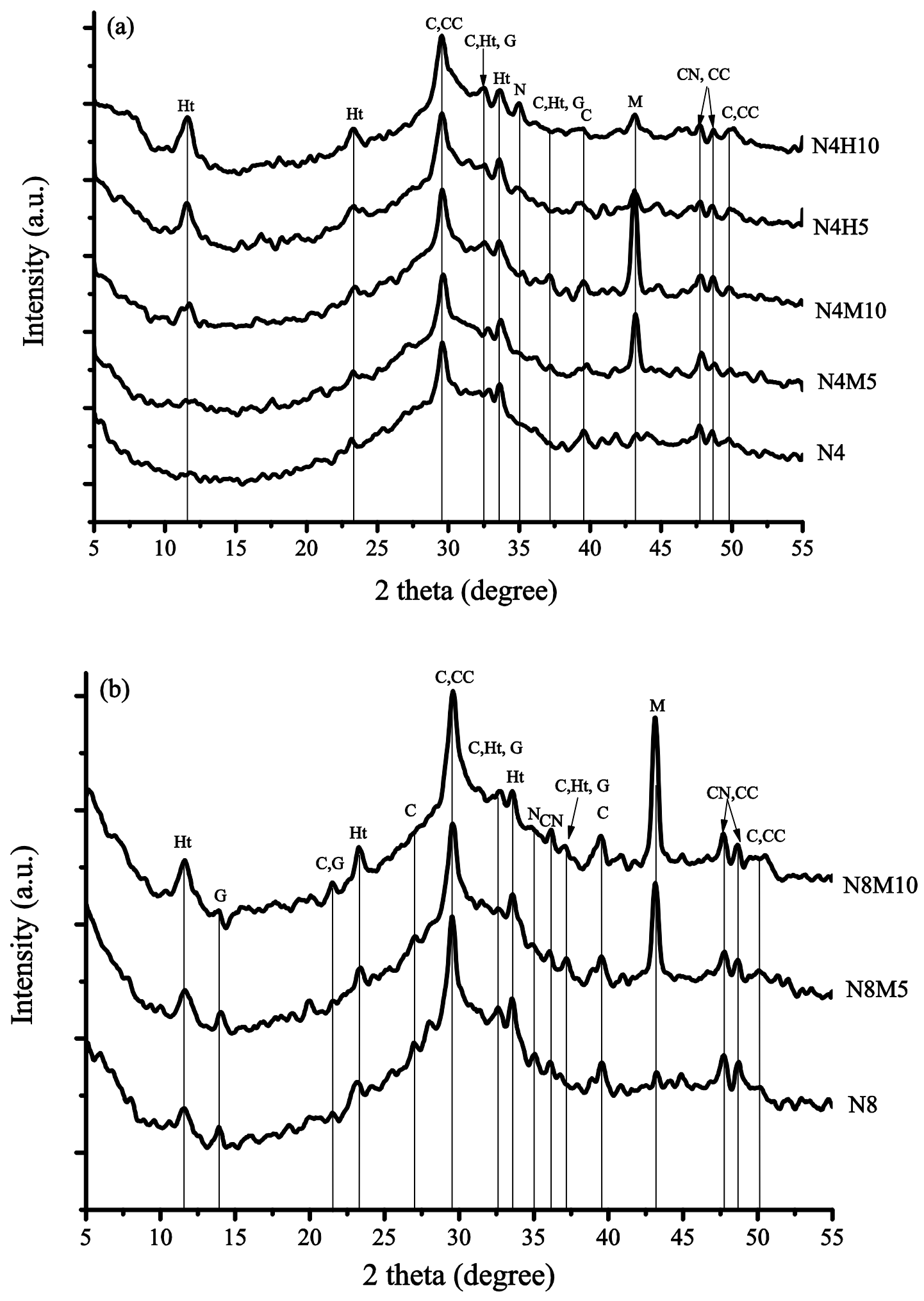

Fig. 4 

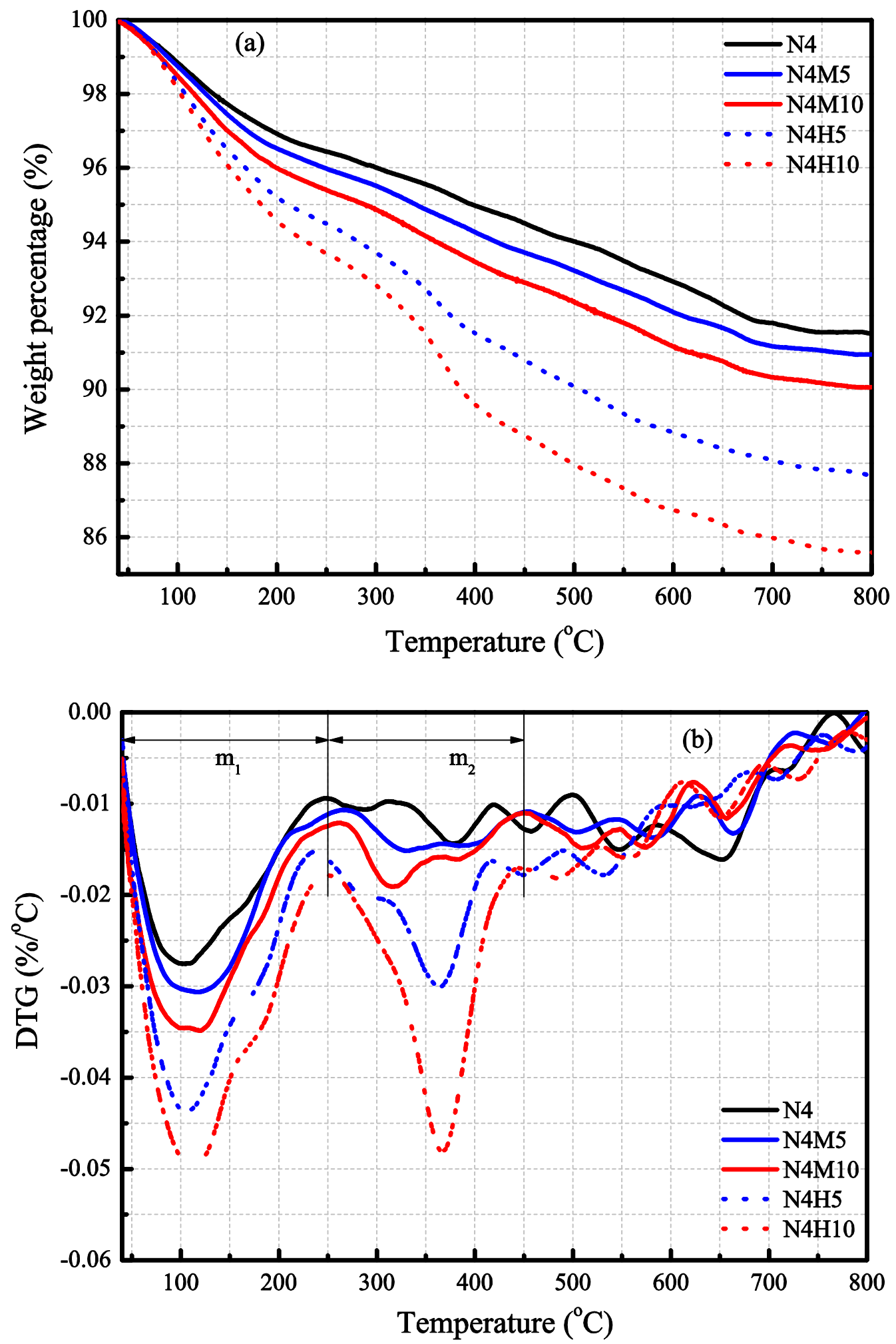

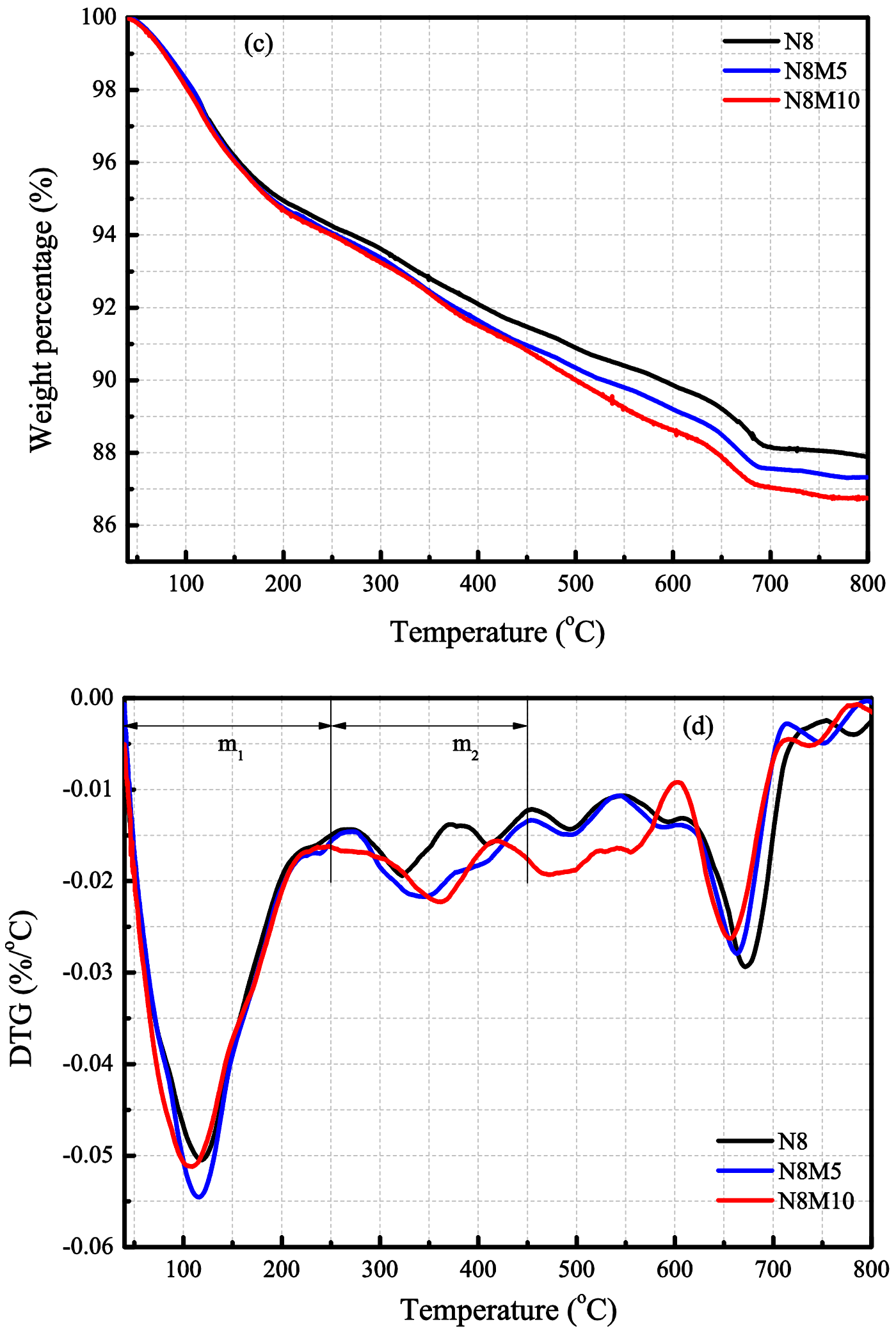

Fig. 5 


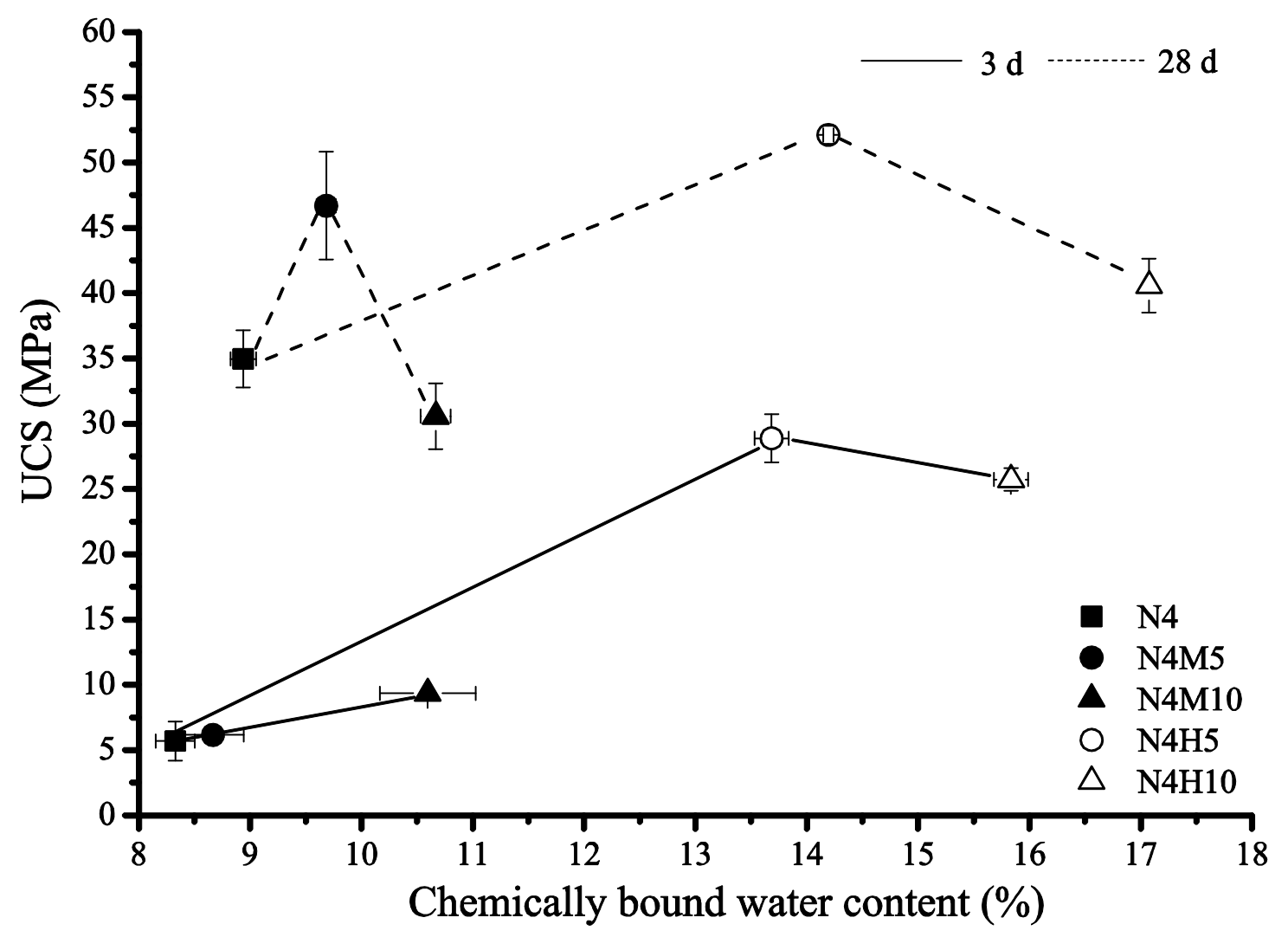

Fig. 6 

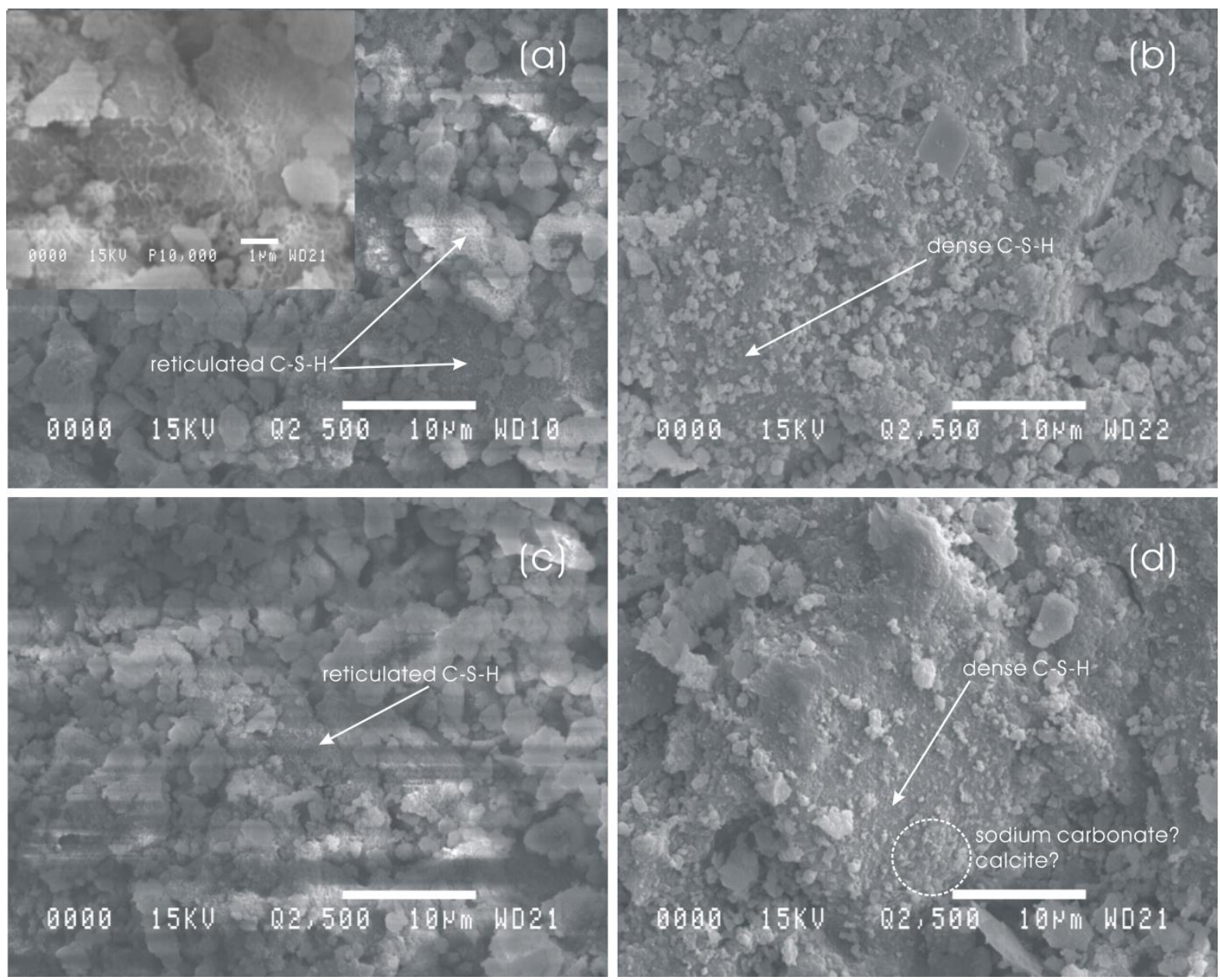

Fig. 7 

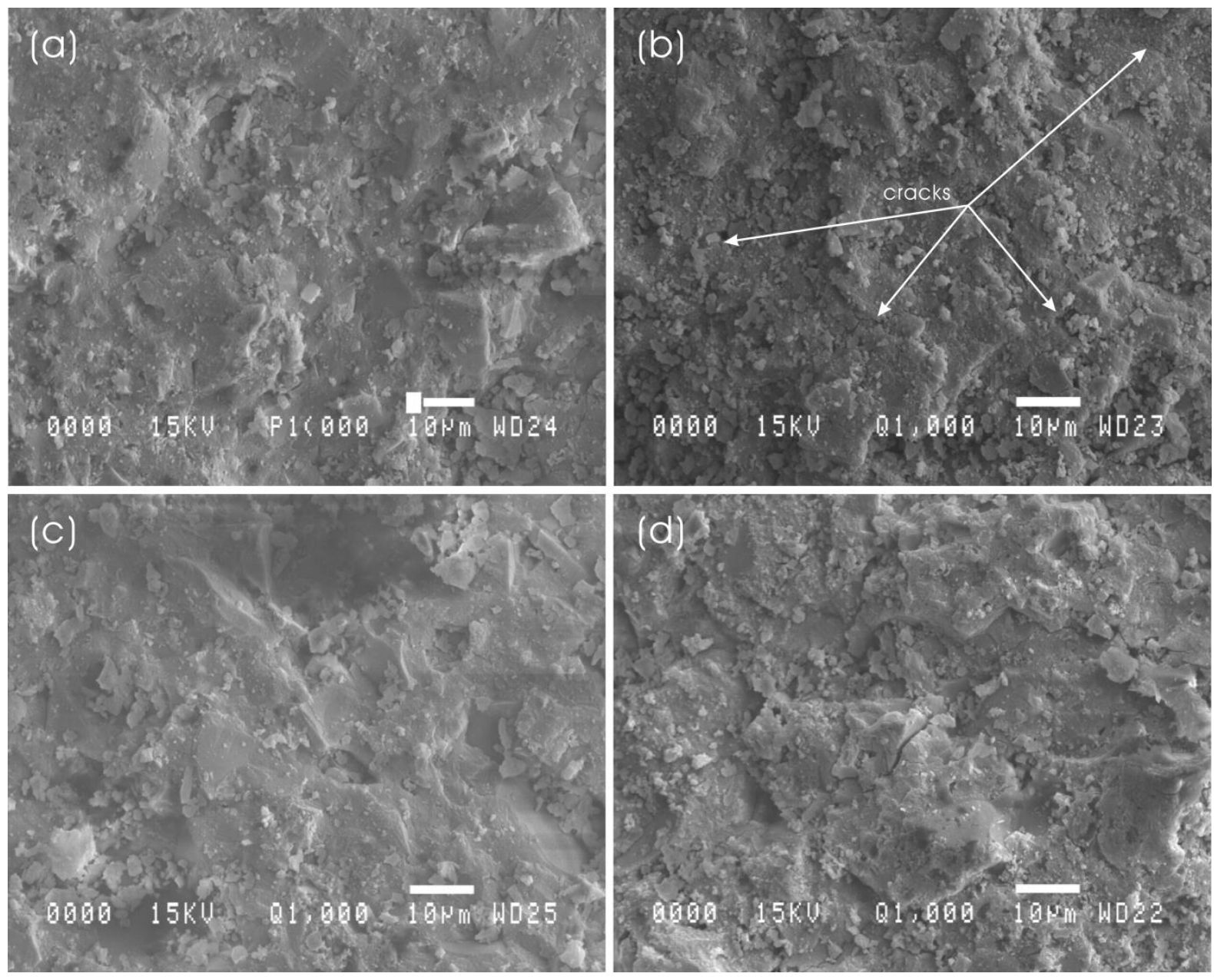

Fig. 8 